\title{
The Cognitive Reading Strategy in Learning English
}

\author{
Syafrida Maiwen ${ }^{1, *}$, Jufri $^{1}$ \\ ${ }^{1}$ Department of English Education, Faculty of Language and Art, Universitas Negeri Padang, Padang, Indonesia \\ *Corresponding author.Email: Syafridamaiwen95@gmail.com
}

\begin{abstract}
The background of this research is the demanding of the students who should study more by themselves and the important of using strategy in comprehending reading text of EFL students in improving their ability in learning English. However, many of the students do not realize these cases and rarely often applying their own strategy in reading. This research aims to investigate the types of cognitive reading strategies mostly used by EFL students. The method used is descriptive. The data were collected trough reading test and questionnaire. The result showed that students are still difficult to understand reading text. Then, it showed every student used different type of cognitive strategy when they are reading. One of cognitive strategy mostly used is practicing. Then, it is expected students always use their own strategy to improve their comprehension in learning English.
\end{abstract}

Keywords: cognitive reading strategy, reading, practicing

\section{INTRODUCTION}

Reading is an important skill among listening, speaking and writing senior high school. This skill is taught by teaching texts or genres. The types of texts are descriptive, recount, and narrative, report, exposition, explanation, procedure, review and news item texts. All of these texts are taught by integrating them to writing skill as it is reflected in basic competences of syllabus of Curriculum 2013.

Although, reading is taught by various genres, it is still difficult to the students to understand the text given for them. Based on the teachers' point of views, the students still had some problems in comprehending reading texts because they were reluctant to read at home. In addition, they did not do exercises and homework seriously. In the classroom, when teachers taught reading text. The students looked bored and did not pay attention to the lessons. Besides, the students were lack of vocabulary and grammar knowledge, text structure, linguistic features and text contents. Then, the students did not have appropriate strategies in reading.

The causes of the problems faced by the students in reading might come from the students' language factors, learning habit and it could also derive from teacher's way of teaching [1]. From students' side, for instance, the factors can be vocabulary, grammar and learning attitudes toward English, especially reading. On the other hand, form teacher's side, it might be materials, media or teaching techniques used by the teacher in teaching. If the teacher could not vary the materials, or did not use appropriate media and did not apply appropriate technique, of course, the students will not study well and finally feel bored to study English.

Beside the factors explained above, the low ability in reading can be caused by students' strategies in comprehending the text [2]. It can happen that the students did not apply appropriate strategy so that they took long time to comprehend the text or could not understand the writer's message. Furthermore, the students might not be able to identify the writer's message because they did not prepare themselves for reading physically or psychologically. All of these can influence the students' comprehension.

Furthermore, O'Malley \& Chamot[3] say that the cognitive strategies are closely linked to specific learning tasks and they are used in the learning process, including repetition, translation, grouping, resourcing, note-taking, deduction, elaboration, imagination and inference. They define cognitive strategies as "operating directly on incoming information, manipulating it in ways that enhance learning." The cognitive strategies that are involved in reading activities include relating new words to a word in memory or writing down the main idea; outlining key points or making a brief summary of the text in order to comprehend the text better.

Then, they propose that "cognitive strategies including repetition, directed physical response, translation, grouping, note-taking, deduction, recombination, imagery, auditory representation, key words, contextualization, elaboration, transfer and inference."

In addition, Suyitno[4] analyze the cognitive strategy use in reading and its contribution to students' achievement. The researcher used reading comprehension test to measure students' reading ability and questionnaire as information of cognitive reading ability used by the students. This study showed that students have variety comprehension and strategies in reading.

Ghafournia[5] says that learners should capitalize on their language treasure as well as strategic potentially to improve reading efficiency. Hence, learning strategy holds significant role in enhancing students' ability in comprehending text. The function of strategies for the 
researcher random seven class of second grade students of MAN 1 Solok and took two classes as sample of this research. After random the class, the researcher got two classes as sample, they are class XI. 1 and class XI. 7.

\subsection{Intrumentation of the Research}

Reading test was used to know the ability of the students in reading. The reading test was used to get students' scores and these scores are expected to give the description of the students' ability in reading.

Then, in order to know the types of reading strategies used by the students, the researcher used questionnaire. The questionnaire was based on the strategy given by O'Malley \& Chamot[3]. In this case, the researcher focused on cognitive strategy because it is appropriate to the senior high school students. Then, the options of the questionnaire were based on Likert Scales. The scales are always, often, sometimes, seldom and never.

\section{FINDINGS AND DISCUSSION}

\subsection{Findings}

The researcher classify the strategy used by the students based on the classifying their ability in reading. Furthermore, the classifying of students' ability in reading, it can be seen in the appendix

There are 10 students who got high ability, 35 students who got moderate ability and 17 students who got low ability.

There are 16 items of the questionnaire which was developed from indicators of cognitive strategy in reading by Oxford[9], O'Malley \& Chamot[3]. The items are divided into four main indicators, namely, practicing, receiving and sending message, analyzing and resourcing, and creating structure for input and output. Furthermore each indicators were divided into sub indicators.

Then, the researcher identified which strategies that mostly used by the students based on their ability in reading. The distribution of the strategies used by the students viewed from their ability in reading can be seen in the following table.
The population of this research is second grade students of MAN 1 Solok. In this case, they are in academic year 2018/2019 as population which consists of seven classes with total number 203 students as population. Furthermore, cluster random sampling is used in order to get sample of this research. In order to get sample, the 
Table 1 The Distribution of Percentage Strategy Used by the Students with High Ability

\begin{tabular}{|l|l|c|c|}
\hline No & $\begin{array}{l}\text { Indicators of Reading } \\
\text { Strategy }\end{array}$ & Percentage (\%) & Classifying \\
\hline 1 & Practicing & 72 & Enough \\
\hline 2 & Receiving and sending message & 92 & Very High \\
\hline 3 & Analyzing and reasoning & 71 & High \\
\hline 4 & $\begin{array}{l}\text { Creating structure for input and } \\
\text { output }\end{array}$ & 85 & \\
\hline
\end{tabular}

Based on the table above, it shows students with high ability got $72 \%$ in using practicing strategy. It means they are tended to use practise strategy in reading text. Then, it shows students with high ability got $92 \%$ in using receiving and sending message strategies. It means they are tended to use these strategy in reading text. In using analysing and reasoning strategies, the percentage is $71 \%$. It means they are tended to use these strategy in reading text. In using creating structure for input and out put strategy is $85 \%$. It means they are tended to use this strategy in reading text.

From the tables above, it can be said that students with high ability mostly used, ptacticing, receiving and sending message, analysing and reasoning, and creating structure for input and out put strategies in reading text.

Furthermore, the students with moderate ability tented to use practice and analyzing and reasoning strategies in reading as following tables:

Table. 2 The Distribution of Percentage Strategy Used by the Students with Moderate Ability

\begin{tabular}{|l|l|l|l|}
\hline No & $\begin{array}{l}\text { Indicators of Reading } \\
\text { Strategy }\end{array}$ & Percentage (\%) & Classifying \\
\hline 1 & Practicing & 71 & Enough \\
\hline 2 & Receiving and sending message & 62 & Low \\
\hline 3 & Analyzing and reasoning & 71.1 & Enough \\
\hline 4 & $\begin{array}{l}\text { Creating structure for input and } \\
\text { output }\end{array}$ & 67 & Low \\
\hline
\end{tabular}

The table above shows students with moderate ability are tended to use practice strategy because the percentage of their response is $71 \%$. Then, it shows students with moderate ability got $62 \%$ in using receiving and sending message strategies. It means they are not tended to use these strategy in reading text. In using analysing and reasoning strategies is $71.1 \%$. It means they are tended to use these strategy in reading text. In using creating for input and output strategies. It means they are not tended to use these strategy in reading text.

Meanwhile, students with low ability are tended to use practice ability in reading test, it shows in the following table:

Table. 3 The Distribution of Percentage Strategy Used by The Students with Low Ability

\begin{tabular}{|l|l|c|c|}
\hline No & $\begin{array}{l}\text { Indicators of Reading } \\
\text { Strategy }\end{array}$ & Percentage (\%) & Classifying \\
\hline 1 & Practicing & 79 & Enough \\
\hline 2 & Receiving and sending message & 53 & Low \\
\hline 3 & Analyzing and reasoning & 65 & Very Low \\
\hline 4 & $\begin{array}{l}\text { Creating structure for input and } \\
\text { output }\end{array}$ & 48 & \\
\hline
\end{tabular}


The table above shows students with moderate ability are tended to use practice strategy because the percentage of the percentage of their response is $79 \%$. However, they are not tended to use receising and sending message strategies because the percentage of their response is $53 \%$. In using analyzing and reasoning strategy is $65 \%$ and in using creating structure for input and output is $48 \%$. It means that the students with low ability are not tended to use the strategy of analyzing and reasoning and creating structure for input and output.

From the analysis of the data, it shows that students with high ability tended to use practicing, receiving and sending message, analyzing and reasoning, and creating structure for input and output strategy. However, students with moderate ability are tended to use practicing and analyzing and reasoning strategy. Then, students with low ability are only tended to use practicing ability. It means that students who use some strategies in reading have good score than students who use less strategy.

\subsection{Discussion}

In order to know what strategy mostly used by the students in reading based on their ability, the researcher used reading test and questionnaire. The test was used to know the students ability in reading which is divided into low, moderate and high. Then, the indicators of the questionnaires are suggested by Oxford. There are three indicators, they are practicing, receiving and sending message, analyzing and reasoning, and creating structure for input and output. These indicators develop into sub indicators, for practicing is repeating and recombining or grouping, for receiving and sending message is getting the idea quickly, resourcing, predicting, and guessing; for analyzing and reasoning is reasoning deductively, analyzing expression or breaking down and translating; for creating structure for input and output is taking notes, summarizing and highlighting.

There are 16 questions answered by the students based on sub indicators. The students chose the categorized such Always, often, sometimes, rarely, and never. Every categorized has scale from 5 to 1 . Then, this scale used to identify the strategies tended to use by the students. The researcher counted the students' response in the questionnaire based on their ability.

After getting the students' response of reading strategy, it showed that students with high ability tended to use practicing, receiving and sending message, analyzing and reasoning and creating structure for input and output. This tending was got from the percentage of them, the practicing is $72 \%$, receiving and sending message is $92 \%$, analyzing and reasoning is $71 \%$, and creating structure for input and output is $85 \%$. This percentage showed that students with high ability mostly used the strategies stated by Oxford[9].

Meanwhile students with moderate ability tended to practicing and reasoning and analyzing strategy. It was showed from the percentage of their response in the questionnaire, practicing is $71 \%$ and reasoning and analyzing strategy is $71.1 \%$. Then, students with low ability tended to use practicing only because the score of practicing strategy is $79 \%$. Yusuf[10] mentioned that scale of students score more than 70 is enough or high, however under 69 is low.

Additionally, the researcher interviewed 21 students they are 7 students from high ability in reading, 7 students from moderate and 7 students from low. This interview was recorded by using hand phone recording and it was conducted after giving reading test and questionnaire. The result of interview showed most of the students mentioned that they always repeat to read the text. Some of them said they repeat to read for several time of continuously repeating, but sometimes for once repeating if the text is not more difficult.

Most of the students answered that they used dictionary to find difficult word. Students with high ability mentioned that they sometimes use word by word translating if they never know that word, and use full translating if they know several words. However, students with moderate and low ability mostly use word by word translating by using dictionary.

Then, students with high ability mostly use skimming and scanning to understand reading text. They use fast reading to get the idea quickly, however for students with moderate and low ability was hard for them to use this strategy. This factor makes them to read and understand the text fast.

Related to use the strategy for creating structure for input and output, it is mostly used by the students with high ability. In the interview, it is based on the question number 11 which is about the students who tend to use highlighting strategy when they found difficult word of difficult words. However, the students with moderate and low ability are not tended to use it.

Furthermore, reading strategy is one factor that influenced the students' ability in reading text. If the students often use more than their own strategy, it help them to understand kind of texts. In line with Ghafournia[5] mentioned that strategy holds significant role in enhancing students' ability in comprehending text. Strategy that used by the students could enhance their learning, perform specified test, and solves specific problems.

Then, Khezrlou[7] mentioned that cognitive reading strategy had positive impact on students' reading development. It could improve the students' ability in reading. Furthermore, Afdaleni[8] said that the successful and unsuccessful students in reading is influenced by the strategy that they used in reading. Based on the studies above, it can be said that the using of strategy in reading is important. By using strategy in reading, it could improve the students' ability in reading.

\section{CONCLUSION}

Based on the findings and discussion above, it can be concluded that students with high ability tended to use practicing, receiving and sending message, analyzing and reasoning and creating structure for input and output 
and students with low ability tended to use practicing

strategies. However, students with moderate ability tended to use practicing and analyzing and reasoning strategies Furthermore, the cognitive reading strategy is important to the students in order to improve their ability and comprehension in reading.

\section{REFERENCES}

[1] A. P. Gilakjani and N. Sabouri, "A Study of Factors Affecting EFL Learners? Reading Comprehension Skill and the Strategies for Improvement," Int. J. English Linguist., vol. 6, p. 180, 2016.

[2] A. P. Gilakjani and N. Sabouri, "How Can Students Improve Their Reading Comprehension Skill?," J. Stud. Educ., vol. 6, p. 229, 2016.

[3] J. . O'Malley and A. V. Chamot, Learning Strategy in Second Language Acquisition. Cambridge: Cambridge University Press, 1990.

[4] I. Suyitno, "Cognitive Strategies Use in Reading Comprehension and Its Contributions to Students' Achievement.," IAFOR J. Educ., vol. 5, no. 3, pp. 107$121,2017$. strategy.

[5] N. Ghafournia, Language Learning Strategy Use and Reading Achievement. Iran: Department of English, Neyshabur Branch, Islamic Azad University, 2014.

[6] M. I. Sari, "Cognitive and Metacognitive Reading Strategy Use and Reading Comprehension Performance of Indonesian EFL Pre-service Teachers," $J$. Foreign Lang. Teach. Learn., vol. 1, no. 2, 2016.

[7] S. Khezrlou, "Cognitive Strategy Training: Improving Reading Comprehension in the Language Classroom," J. Teach. Lang. Ski., vol. 3, no. 4, 2012.

[8] A. Khandari, A. B. Setiyadi, and A. Nurweni, "Identifying Learning Strategies Between Successfuland Unsuccessful Learners in Reading Comprehension," $U$ JET, vol. 4, no. 6, 2015.

[9] R. L. Oxford, Language Learning Strategies: What Every Teacher Should Know. United States of America: Newbury House Publisher, 1990.

[10] S. Arikunto, Penelitian Tindakan Kelas. Jakarta: Bumi Aksara, 2008. 